\title{
LEGAL AND ORGANIZATIONAL SUPPORT FOR THE LAND REFORM BY THE P. STOLYPIN GOVERNMENT
}

\section{Zakharchenko P. P.}

\section{INTRODUCTION}

Political and legal prerequisites that formed in the country at the beginning of the 20-th century matured before a cardinal decision was made. They were pushed by the head of the state himself. At a meeting with the peasant delegation in January, 1905 in Tsarskoe Selo, Nicholas II outlined ways of implementing the land reform. He unambiguously declared the inadmissibility of the liquidation of the landed estates the delegates insisted on. "The land owned by the landlords belongs to them in the same inalienable right that your land belongs to you"1, - this replica of the emperor would later be repeatedly relayed, first of all by P. Stolypin, who would act within the frames defined by Nicholas II.

Finally, on November 9, 1906 nominal decree of Governing Senate "On amending some regulations of the present law relating to peasant land tenure and land use" allowed "each homeowner who owns the allotment of land by public law, to require the transfer of personal property due to his part of the designated land". If no redistribution of land had been carried out in communities for 24 years, it was transferred into personal property without a compensation to the community (Section 1, Article 2). "The allotted land of the court is privately owned and does not require documentary evidence",- such a statement of the Ministry of Internal Affairs of August 4, 1907 under No. 23792 de jure without unnecessary procedures recognized a considerable percentage of peasants of Ukrainian provinces as the owners of the lands. Otherwise, individual homeowners purchased land plots for free only when in their families the number of audit souls after the last redistribution had not decreased. Otherwise, the homeowner was obliged to make payments to the community in the amount of the initial average purchase price of one tenth for the surplus plot (Article 3).

As the civil legislation of the Russian Empire did not contain a definition of "personal property", the Chairman of the Council of Ministers, State Secretary P. Stolypin, at the insistence of the State Duma deputies, was forced

\footnotetext{
${ }^{1}$ Боханов А.Н. Последний царь. М. : Вече, 2006. 512 с.

2 Закон 9 ноября 1906 года о выходе из общины, с разъяснениями. М. : Юристь, 1908. $85 \mathrm{c}$.
} 
to clarify the Government's understanding of the mentioned legal definition. On December 5, 1908, in a speech at the session of the State Duma of the third convocation, he stated: "An individual owner in accordance with the text of the law has the right to dispose of his land, may acquire it as well as may require to transfer some of its plots to one place; he may purchase land for himself additionally as well as to mortage it in the Peasant Bank; finally, he may sell it"3.

At the same meeting P. Stolypin as the representative of the subject of representation of the legislative initiative, expressed himself about the main idea of the law. According to the head of the Council of Ministers, it was necessary "where the personality of the peasant has developed to some extent and where the community, as a forced union, impedes his activity... to give him the freedom to work, to get rich, to dispose of his property, to give him power over the land"4.

\section{Nominal Decree to the Governing Senate "On the Supplement to Some Resolutions of the Present Law Concerning Peasant Land Tenure and Land Use" November 9, 1906 : Characterization of the Source of Law}

After all it was the community as a hotbed of accumulation of left-wing radical ideas that the authorities considered a real threat to their existence. No wonder, one of the members of the State Duma, A. Eropkin, expressing the sentiments of the right circles of the political spectrum, warned: "The community denies the right for private land ownership; and this denial penetrated so deeply into the minds of the members of the community that it consistently came as far as the point of not accepting the property at all"5. Such sentiments in the right segment of the political landscape P. Stolypin also belonged to, were far from unique.

According to the provisions of the Law of November 9, 1906, peasants of all names who had purchased plots of public land into private ownership continued to retain the right of use with unchanged share, as well as up to the moment of the declaration of intention to transfer to personal possession, and of those lands, which were distributed on special grounds (hayfields, forests, etc.). Similarly, their rights were maintained, according to the community's customs in force for worldly homesteads, pastures, pastures, vows.

3 Александровский Ю.В. Закон 14 июня 1910 года об изменении и дополнении некоторых постановлений о крестьянском землевладении. СПб. : Товарищество по изданию новых законов, 1911. $608 \mathrm{c}$.

${ }^{4}$ Столыпин П.А. Думские речи. М : Знание, 1990. 64 с. (Новое в жизни, науке, технике. Серия “Лекторское мастерство”. № 10).

${ }^{5}$ Бородин А.П. Реформы во имя России. М. : Вече, 2002. 380 с. 
Article 16 clarified that peasant homeowners, having acquired land on personal property rights, enjoy the same rights with the owners of the yards. That is, the heirs of the former continued to retain the right to participate in the use of lands which were allocated under special conditions, and of those that ones were not distributed at all by the decision of the community.

In view of the problem we are investigating, the third section of the analyzed Law is of major importance to us. It is this law that covers the legal personality of the owner of the land, the volume of his rights and the mechanism of securing public land as his personal property. "Yard plots Article 1 of Section 3 reads - granted to the peasant yard posession of the peasants upon their allotment of land and acquired later into the personal property of individual peasants from public lands as well as yard plots in public land use, constitute the personal property of the landowners, on whom these plots are designated in accordance with the acts of land management, decisions of communities, decisions of peasant bodies, acts of alienation and decisions of court places" ${ }^{\prime 6}$. It was the courts space, and in this case that county courts that were made responsible for solving the homeowners question in case of his absence in the family. According to the area's custom in force, the courts approved the relevant decision, taking into account the following circumstances: to whom of the members of the family, by distribution or last redistribution, the allotment was given; on whose name the payment book was written; who paid the duties; who by the time of acquisition, actually owned and cultivated the allotment ${ }^{7}$.

As we can see, the text of the Decree of November 9, 1906 does not answer the question of the concrete owner of the land holdings. The Western provinces with a yard form of use of allotment land, including the Podolsk and Volyn, gubernias are taken as a standard. For these reasons, the law did not apply to them. It was here that the rule had long been enrooted that the land belonged not to the yard, but to the homeowner as the head of the family. In short, according to the Decree of 9 November 1906, yard plots in the yard posession transferred into personal property from the public allotment land as well as homesteads in public ownership, were recognized as the property of the homeowner (father or grandfather), but not that of the family in its full composition. This conclusion is prompted by the absence of any other

6 Закон 9 ноября 1906 года о выходе из общины, с разъяснениями. М. : Юристь, 1908. $85 \mathrm{c}$.

${ }^{7}$ Соловьев И. Юридическое наставление крестьянам как укрепить в собственность земельный надел и как владеть землею на правах собственника с приложением Закона 14-го июня 1910 года. М. : Типография “Наше слово”, 1911. 32 с. 
interpretation of the concept of "personal land ownership" than we have found the previously issued and analyzed normative legal acts.

Such is the logics of our speculations. However, the opinion of the Governing Senate was different. With the passing of the well-known Decree, the Senate faced a large number of complaints, statements and protests and thus interpreted the mentioned norm in another way. The Second department of the Senate on 31.01.1907 (№ 735) approved the decision unexpected for the contents of the decree: "Data on land allotments bought by peasant are issued to the name of the homeowner, while the plot is considered belonging to the whole yard" ${ }^{8}$. So, the right for land ownership after its acquisition as private property continued to belong to the peasant yard.

Meanwhile, common property included indivisible plots of land of few people who did not have family vertical ties (Section 3, Article 2). As noted, as the joint ownership of Art. 543 Vol. X Part 1 of the Laws of Civil Law recognized such a type property where the right for one thing belongs to several persons, each of them having full powers only on a known part of the thing ${ }^{9}$. In the context of Article 2, Section 3, the Decree refers to the indivisible land plots of several persons. Of course, the majority of such persons were mothers, brothers, uncles, nephews or other relatives on a side rather than a straight line ${ }^{10}$. If it was such persons who concentrated the powers of the homeowner, the land plots constituted the joint ownership of the host, jointly with the side relatives. Contemporary lawyers have argued not without grounds that in this case the latter had the right to demand the allocation of their share of movable and immovable property from joint ownership. However, in order to achieve this goal, it was necessary to obtain the consent of the homeowner for legal family distribution. Children not separated from their parents' state were not allowed to require the transfer of ownership to their own names (MIA Circulars of 23 November 1905 and 6 June 1907).

Consequently, the statutory provisions of the Decree governed the procedure for leaving public custody. For this purpose, it was assumed that those wishing to leave the community and to allocate the land allotment from

\footnotetext{
${ }^{8}$ Тютюрмов И.М. Закон 14 июня 1910 года об изменениях и дополнениях некоторых постановлений о крестьянском землевладении с законодательными мотивами и разъяснениями Правительствующего Сената (по 1 сентября 1910 года). - [изд. неоф.] СПб.: Издание юридического книжного магазина И.И. Зубкова под фирмою “Законоведение", 1911. 181 с.

${ }^{9}$ Семенов Е.В. Краткие сведения по русскому земельному праву : пособие [для учеников землемерных училищ]. Псков : Тип. губернского земства. 35 с.

${ }^{10}$ Дроздов В.П. Крестьянские законы. Права крестьян на землю. М. : Тип. П.П. Рябушинского, 1910.39 с.
} 
the land use had to apply to the village elder. The latter, in his turn, was to convene a village assembly, which within one month from the date of the application was obliged to make a decision on the transfer of land on the right of personal property. Half of homeowners were required to make a decision, and at least half of the participants of the meeting were to vote for the decision to transfer the land into personal property.

It should be noted that the legislator did not envisage a possibility of turning down the allocation of land to the homeowner. In the event of the community not wanting the land to be allotted, the applicant was allowed to contact the local governor or other officials. The chiefs of the country or the persons who replaced them were to satisfy the request of the homeowner immediately. For this purpose, the officials had to go to the place, to draw up an appropriate act to reflect the parameters of the lands that were subject to transfer to the personal property of those wishing to leave the community. In case of delay of the procedure by the district governors, the homeowner could apply to the local provincial administration.

The decisions of rural communities as well as rural chiefs' decrees entered into force and were performed only after their approval by their county congresses. It was here that complaints of both homeowners who had purchased the land into personal property and authorized for that representatives of the community were handled.

Despite the extension of the powers of the homeowner to allotment lands, the legislator did not eliminate the legal restrictions laid down in the Regulations of February 19, 1861 and expanded by the decree of December 14, 1893 "On the inalienability of allotment lands". Restrictive norms regarding the sale of allotment land to peasants belonging to the seller's communities continued to apply.

An important instrument for the implementation of the state's land policy was the provision on the possibility of transition of entire communities with both public and backyard land use to household cut land. It should be noted that departures to household cuts be made, as some authors mistakenly claimed, not only by peasants with acquired lands, but also by those individuals or legal entities whose land was in the right of use. For a transition to household cut plots, a decision of the rural assembly by a number of $2 / 3$ votes of peasants who had the right to participate in the meeting was considered sufficient (Part 4, Article 1). It was this Article that was the spearhead, as A. Kofod noted, which was aimed at the destruction of the community ${ }^{11}$.

11 Зырянов П.Н. Крестьянская община Европейской России: 1907-1914. М. : МГУ, 1992. 286 c. 
So, the Decree of November 9, 1906 opened a real opportunity for individuals and their families to stand out from the community, to obtain their share in personal property, even if the community objected to such an operation. The very fact of the emergence of an alternative between public and personal land tenure testified, at least in the area of land relations, that Russia had firmly defined its vector - the orientation towards integrated European values.

Subsequently, a serie of regulations made a number of additions and explanations to the voiced articles of the Decree. Thus, by the decision of the Senate of September 23, 1883, supplemented on February 17, 1907, women were made equal in rights with their male homeowners. However, irrespective of the gender of the homeowner, it was considered unlawful to acquire part of the peasant's allotment into personal property. From August 31, 1907 the Ministry of Internal Affairs, declared the inadmissibility of such steps, since "the transition to personal ownership of allotment land is accompanied by a withdrawal from the community" $"$. In short, the land was allowed to be acquired on the right of personal property in the full volume of the existing allotment, and not individual parts of it.

Authorized authorities dedicated much of explanatory work to clarifying the essence and contents of regulations of acquiring the allotment of land into personal ownership by homeowner's family. Thus, the Circular of the Ministry of Internal Affairs of June 6, 1907 prevented the right of the lateral relatives of the homeowner to demand the transfer of their share of allotted land into personal property, unless they achieved legal family distribution and became its independent users. The circular also expanded the ownership powers of the owner of the estate. It was only by his consent that it was allowed to acquire the land into the personal property of non-detached family members who resided with the homeowner.

In the same way, on July 7, 1907, the Ministry of the Interior Affairs spoke about the peculiarities of individuals who claimed the status of a landowner. It recognized only the homeowner-ancestor, who on the personal property right used, owned and disposed of plots from public land acquired by individual owners, as well as of yard allotments granted to peasants by Local Regulations on February 19, 1861, and estates in public land tenure. It was the homeowner who owned the personal property right he disposed of at his own discretion, regardless of the collegial or individual opinion of the rest of the family members ${ }^{13}$.

12 Закон 9 ноября 1906 года о выходе из общины, с разъяснениями. М. : Юристъ, 1908. $85 \mathrm{c}$.

${ }^{13}$ Там само. 
In spite of the government's attempts to decisively restrict public ownership by legal means by granting legal advantages to the land property allocated from the personal property of the secular land, the provisions of Articles 13 and 135 of the General Regulations on the Peasants for the Use of Local Customs in legal disputes on the Inheritance of Peasant property were not reconsidered. However, the court was to establish the reality of the existence of a custom. Otherwise, the lawsuit was conducted on the basis of general civil laws (MIA Circular No. 70 of December 9, 1906) ${ }^{14}$.

\section{Decree of November 9,1906 and the provisions of February 19, 1861 in terms of comparative law}

Analyzing the Decree of 9 November 1906 as well as explanations and additions to it, we find it necessary to emphasize existent discrepancies between the its regulations and the Regulations of February 19, 1861 This need arose in order to objectively and impartially rethink the contents of the document, which, in concept, was only to disclose and supplement the known Art. 36 of the General Regulations on Peasants, edited in 1861 (or Article 12 of the General Regulations, published in 1902). There is every reason to claim that by its contents the Decree went far beyond the title of the article. That is what our speculations are based on:

Firstly, comparing the texts of Art. 36 of the General Provisions on Peasants and the Decree of 9 November 1906 one can notice the inconsistency of their contents with each other. Thus, if in the first case there is a mention of the transfer of allotment land to the property only if it was acquired as a result of the purchase, and the sum for carrying out this operation was to be collected from all members of the community by distribution, then in the second case it concerns all allotment land irrespective of the method of their acquisition;

Secondly, the Decree takes into account not the fate of the individual homeowner's participation in the acquisition of land, as provided for in Art. 36, but only actual use without taking into consideration the changes in the size of the plot over the time of transition to redemption until the cancellation of redemption payments. In an other words, the basis of the acquisition of land ownership and the size of the plot was not the contributions of members of the community made in the form of redemption debt, but only a secular distribution. The famous land law researcher of Russia F. Samarin drew attention to this legal collision. If, for many years, a homeowner made payments for the plots of land of several audit souls, members of his family, and their number diminished for some reasons upon

\footnotetext{
14 Там само.
} 
the acquisition of the whole plot as entire property, he had to repay the land price of the lost audit souls ${ }^{15}$;

Thirdly, the General Regulations on Peasants of February 19, 1861 made it possible for an individual member of the rural community to demand for themselves only the allotment of land, while under the Decree of November 9, 1906, the allotment was to be preceded by the acquisition of land plots into the personal property of the homeowner. The fundamental difference between them was that according to Art. 36 of the General Regulations, the allotted land continued to be in public domain, while under the Decree the allotment land was transferred to the individual homeowner as full personal property on condition of its separation in kind from the secular land;

Fourthly, Art. 36 provided for monetary compensation to the peasant in case of inconvenience or inability to make the separation. Under the rules of the Decree of 9 November 1906, the community was obliged to satisfy the homeowner's demand to withdraw from the community, and to acquire land in private ownership. In case the rural assembly did not want to fulfill the requirement, the land transfer was forced by administrative order. Monetary compensation was paid only if the community could not satisfy the homeowner's request for the allocation of land to one place. However, if the allocation coincided with the general redistribution of land, the community was deprived of the right to replace it with cash payments;

Fifthly, a deep division occurred during the legalization of one of the subjects of property rights for allotments. If the Regulations of the Peasant Reform referred to family property (Articles 93, 98 of the Little Russian Regulations; Article 129 on Redemption Regulations), it was already denied in the Decree of November 9, 1906. The new legal structure - personal land ownership - became standardized. Family property became a legal relic. Researchers are inclined to believe that by changing the wording of this provision, the Decree cancelled a serie of explanations and legal interpretations made by the Senate's departments during $1880-1890^{16}$.

Therefore, contrary to the position declared by the head of the state during the signing of the Decree of November 9, 1906, on the unshakability of the fundamental principles of the Regulations on February 19, 1861, we have foundations to argue that he had gone far beyond the provisions of the Reformed Legislation by the contents and nature of the legislative measure. A comparative correlation of just one Art. 36 of the General Regulation on the

\footnotetext{
${ }^{15}$ Самарин Федор. Указ 9-го ноября 1906 года и Положение 19-го февраля 1861 года. М. : Печатня А. И. Снегиревой, 1908. 16 с.

16 Ламздорф П.К. Высочайший Указ 9 ноября 1906 года и семейная собственность у крестьян. СПб. : Сенатская типография, 1909. 27 с.
} 
peasants with the contents of the Decree testifies to the clear but not advertised intention of the authorities of the Russian Empire to lay the legal foundations for removing obstacles to the rural homeowners in securing the land in personal property. The validity of the imperial act extended to the territories of those provinces in which the public character of land ownership prevailed. The western provinces of Russia, including Podolsk and Volyn gubernias with yard-hereditary system of land tenure, were not subject to the Decree of November 6, 1906. With the elimination of redemption payments on January 1, 1907, the owners of these provinces automatically acquired the status of owners of allotment lands.

The Organizing and Coordinating Center responsible for the implementation of the land reform provisions was designated the General Directorate of Land Management and Bakery (hereinafter referred to as CDLM). The Land Management Committee was established within the management; it was in charge of the activities of county and provincial land management commissions. According to the researchers, it was they which were given the role of active leaders of reformist ideology in places ${ }^{17}$. According to Art. 4 of the first Decree "On Land Management Commissions" of March 4, 1906, they were in charge of issues related to the relocation of peasants to vacant lands: assisting rural communities in using the best experience in allotment land cultivation; on a contractual basis implementating the layout of the stripland; dividing large rural communities into smaller territorial units.

Under the "Regulations on Land Management" of May 29, 1911 the composition of the commission expanded. It included one representative of the judiciary and a parish elected by the peasants of the country case was considered in ${ }^{18}$. Article 100 laid down the conditions for recognizing the legitimacy of decisions of county and provincial land management commissions. It was only with the obligatory participation in the meeting of its permanent member or his deputy, a member of the district court and one of the elected representatives from the Zemstvo or from the peasants the decision of the land management commission was legitimized. The legislator considered such a representation sufficient to minimize the level of wrongful decisions.

The county land management commission was headed by the county leader of the nobility, its members were representatives of similar instances -

\footnotetext{
17 Климин И.И. Столыпинская аграрная реформа и становление крестьянсобственников в России. СПб. : Клио, 2002. 348 с.

${ }^{18}$ Положение о землеустройстве. Полн. собр. законов. Собр. 3. Спб. : Государственная типография, 1914. Т. XXX1. 1914. № 35370.
} 
however, of the county level. Apart from officials appointed to the commission in accordance with their official duties, about half of its members were elected. The representative status in the commission was held by three representatives from the county Zemstvo assembly and three peasants, included by lot from the candidates elected by the village assemblies ${ }^{19}$.

Undoubtedly, the main role in the activities of the land comissions was played by its permanent member, who worked on a constant basis and was responsible for land-arranging work in places. The permanent members of the provincial committees were included in them from 1912 and prior to that time their duties were performed by persons from the number of the oldest officials appointed by CDLM. The candidates for this position in the county commissions were proposed by the local authorities and approved by the Head Office. They were given the following requirements: to have higher education, professional training, experience in land management or peasant affairs management and knowledge of the area.

As we can see, the forming of land management commissions was based on the principle of including in their composition all officials with competence, in one way or another connected with the sphere of agriculture, land relations, including representatives of the peasantry as users of the land granted in the allotment. The peasants were included in the commission for the purpose of presenting their own interests and preventing violations of rights of their stratum.

The land management commissions were called on to streamline land plots of homeowners, who decided to get rid of public land ownership and become their owners. However, the fact of the withdrawal from the community and the acquisition of land did not yet guarantee the mobilization of all scattered lanes into one field. In short, the former public lands, located at a considerable distance from each other, partly due to the possessions of individuals, societies and individual communities, were permanently assigned to the persons to whom the right of ownership of the allotment lands on the basis of personal property was assigned. In this case, the owner lost legal dependence on the community, but continued to be in close land contact with it. Only the Law of June 14, 1910 allowed to collect all strips in one field, that is, to take them to household cuts. As neither the legislation nor the community knew such kinds of land tenure before, the responsibility for their widest possible implementation also rested with the land management commissions ${ }^{20}$.

19 Климин И. И. Столыпинская аграрная реформа и становление крестьян-собственников в России. СПб. : Клио, 2002. 348 с.

${ }^{20}$ Антошкин С. Н. Столыпинская аграрная реформа : [лекция]. М. : МЮИ, 1999. 21 с. 
CDLM as a coordinating and directing institution developed guidelines for local land management commission and recommendations for their use in practice. Land management was recognized as "an operation aimed at changing existing land relations, changing existing forms of land tenure, if it is caused by public expediency and is carried out with a greater or lesser participation of public authorities" 21 .

In another instruction, the Main Directorate defined the contents of land management in the context of land reform provisions. Land management works were divided into two types - single and group ones. The first kind can be called the final form of land management, while the second the preparation for it. The first one included such works as the allocation of acquired lands of individual homeowners from the community to cutting household or farm; distribution (separation) of individual settlements into household cuts or farms. The instruction attributed to group land management such types of land management works that were carried out with the whole group of land tenures, without their allocation to farms and household cuts at the time of the land management itself ${ }^{22}$.

In another instruction, the Main Directorate explained to the provincial and county commissions how household cuts and farms should be interpreted, and what were differences between them. In its interpretation the farm was considered to be a plot of land on which all lands necessary for farming: pastures, arable land, hayfields, farmsteads, water sources were reduced to one place. In the absence of the estate, the land was called a household cut. In addition, if they tried to reduce the arable land to one compact array, then all other lands (hayfields, pastures, forests) could be removed to their household cuts without any connection with arable land ${ }^{23}$. "Given that the most perfect type of land arrangement is a farmstead - quoted paragraph 5 of the Circular of March 21, 1908 - it is necessary to seek a breakdown of the Article into farm plots and only in cases where water supply or other local conditions do not allow to use this Article for sale to farms, it is possible to stop at the arrangement of settlement with the split of the field ground into household cuts or at the sale of the land by household cuts without eviction" 24 .

${ }^{21}$ Хауке О. Русское землеустроительное законодательство. М. : Типолитография, 1910. 157 с. (Выпуск 1).

22 Обзор деятельности Главного управления Землеустройства и Земледелия за 1910 г. СПб. : Тип. В. Ф. Киршбаума, 1911. 380 с.

23 Там само.

24 Державний архів Житомирської області. Ф. 226. Волынская губернская землеустроительная комиссия. Оп. 1. Спр. 776. С циркулярами и циркулярными распоряжениями Главного управления землеустройства и земледелия. Арк. 87-91. Циркуляр комитета по землеустроительным делам от 21 марта 1908 г. № 10. 191 арк. 
On March 19, 1909, the Land Management Committee of the State Agrarian Policy approved, with the signatures of the heads of the central departments, namely ministers or their deputies, "Temporary Rules for Land Management of Entire Rural Communities". Article 27 of the Provisional Rules filled the legislative gap which was not regulated by the Decree of November 9, 1906. It regulated the order of withdrawal of part of the homeowners from the rural community with public land use. The act sanctioned the possibility of allocating in nature the share of the land jointly owned by them, with or without eviction, only provided that a decision was taken by the rural assembly with the participation and consent of all homeowners, candidates for the separation from the community ${ }^{25}$. So, the Rules made it possible for peasants, and first of all, from the number of the poor members of the community in public land use to start farming on privately owned land at a concerted effort.

In a subsequent act, namely by the Decree of November 15, 1906, Nicholas II legalized the right of all categories of peasants who acquired land into personal property and, by decision of the village assemblies, made land allotment in kind outside the community, to get a loan the secured by personal holdings. The subjects of land ownership, such as rural communities, peasant societies, individual owners of suburban areas, as well as those homeowners who allocated their holdings from the public domain, fell into the sphere of regulation of contractual relations (Article 1). In a separate line in the Decree, the Emperor prescribed the right of the Little Russian Cossacks to obtain loans secured by hereditary land estates. However, the restrictions on the Cossack lands existing in the disposal order were not completely cancelled. We are speaking about the possibility of transferring lands with the status of personal property to be mortgaged only to a clearly defined bank - Peasant Land. Commercial banks were not allowed to make transactions with the mortgaged immovables of the Little Russian Cossacks ${ }^{26}$.

In connection with the events of the bourgeois-democratic revolution of 1905-1907 GG and the introduction of the constitutional monarchy in the country, the law-making process in the Russian Empire became more democratic on the one hand and much more complicated on the other. According to Art. 86 of the Basic State Laws, which outlines the procedure for adopting legislative acts, "no new law can be enforced without

25 Там само. Спр. 56. Арк. 85-91. Временные правила о землеустройстве целых сельских обществ от 19 марта 1909 г.

${ }^{26}$ Именной Высочайший Указ Правительствующему Сенату 15 ноября 1906 года. Как могут крестьяне и казаки заложить свои надельные и казачьи земли и для какой надобности разрешается этот залог. Полтава : Типолитография торгового дома И. Фришберг и С. Зорохович, 1907. 38 с. 
the approval of the State Council, the State Duma and that of the Emperor"27. Issued, as well as 7 of other laws of the agrarian complex, with references to Art. 87 in an extraordinary manner between the dissolution of the first and the convening of the second State Duma (July 8, 1906 - February 19, 1907) ${ }^{28}$, the Decree of the Government Senate "On Amendments to some Resolutions of the Present Law Concerning Peasant Land Tenure and Land Use" was to be submitted to the State Duma within two months after its resumption of activity. The government held to the mentioned norm and introduced the bill for discussion on time. Given the need to consider one of the most important land laws, the deputies began discussing the Decree on October 23, 1908 and tried to approve the final decision during 21 meetings of the General Assembly of the State Duma. The document became an object of the six-month discussions at the meetings of the main representative body of the state. Almost 500 speakers took part in the discussion ${ }^{29}$. Only on the last day of the discussion of the Law of November 9, 1906, more than 40 peasants from different regions of Russia participated in the debate. The speakers included peasants' deputies from all Ukrainian provinces, the overwhelming majority of whom supported the Decree and the provisions on the transfer of land from public land ownership to the peasant's personal property. "The peasant needs land, it is necessary to give it to the peasant both having little land and no land, but the peasant needs to get the land as his property", - said from the rostrum a deputy from Chernihiv A. Bazilevich ${ }^{30}$, whose words were consonant to the speeches of the absolute majority of Ukrainian peasant delegates. An understandable clear commitment to private land ownership, including a large one, according to the deputy V. Kuzmin-Karavaev, was manifested by "almost unanimously by the landowners of the Polish Kingdom and Western Territories" ${ }^{\prime 3}$. As we can see, the existing social differentiation between landlords and peasants did not prevent the development of a common position on the need to eliminate public land ownership and to transfer of allotment land to the personal property of the persons who worked on it.

27 Законодательные акты переходного времени, 1904-1908 гг. СПб. : Тов-тво по изданию новых законов, 1909. 982 с.

28 Дякин В.С. Черезвычайное указное законодательство в России (1906-1914). Был ли шанс у Столыпина? : сборник статей. СПб. : ЛИСС, 2002. С. 120-148.

29 Аврех А.Я. П.А. Столыпин и судьбы реформы в России. М. : Политиздат, 1991. $286 \mathrm{c}$

30 Герье В. Второе раскрепощение: общие прения по Указу 9 ноября 1906 года в Государственной Думе и Государственном Совете. М.: Печатня С.П. Яковлева, 1911. $232 \mathrm{c}$.

${ }^{31}$ Кузьмин-Караваев В.Д. “Революционные выступления” Думы и земельный вопрос. СПб. : Б. в., 1906. 42 с. 
In the midst of the debate around the decree, at the insistence of the government, 56 Article was introduced and voted, which temporarily restricted the purchase of land by 6 soul, higher or decree allotments for one person within one county, where the local Great Russian or Little Russian regulations were applied. In the provinces of Right-Bank Ukraine, the purchase was limited to three farmsteads or three foot plots of indigenous land with their homesteads. The State Duma Land Commission noted that the above mentioned allotment restrictions "amount to the double the size of the higher allotment, by the norms of 1861 , of the average composition of the peasant yard today"32. Domestic researcher D. Selikhov quite reasonably believes that the government's position aimed at preventing the concentration of large land latifundias in one hand could be explained by the reluctance of landowners to obtain in the person of the well-to-do peasant a competitor in the agricultural market.

It was not until May 8, 1909 that the decree was approved and transmitted to the General Assembly of the State Council, which elected a special commission of 30 persons to prepare the final conclusion. The latter conducted its work from October 27, 1909 to February 13, 1910, inviting to attend its sittings not only members of the State Council, but also a number of specialists in land relations ${ }^{33}$.

The bill, entitled "Regulations on the Amendments and Supplements to Some Resolutions on Peasant Landownership", received its completed appearance on June 14, 1910. After the signing by Nicholas II of the new Decree, that day the latter was granted the status of a legislative act.

So, from the signing of the Decree on November 9, 1906 until its final approval in accordance with the requirements of the Basic State Laws of 1906, almost four years passed. During the discussion at the General Assembly of the State Council, the Special Commission, and finally, at the third convocation of the State Duma, the original text of the document, which was valid throughout the whole time, was amended and clarified. Among those articles that touched more or less upon the problems of land ownership in various ways, we can distinguish the following ones:

1. From Art. 1 of the Decree of November 9, 1906, recognizing those who had passed on to the court and hereditary possessions of both the community and the individual villages, which had never made any land

32 Селіхов Д.А. Аграрне законодавство царської Росії в Україні епохи капіталізму (друга пол. XIX - поч. XX ст.). : автореф. дис. на здобуття наук. ступеня канд. юр. наук.: спец. 12.00.01. “Теорія та історія держави і права; теорія та історія політичних і правових учень”. Х. : Б. в., 2002. 20 с.

${ }_{33}$ Сидельников С. М. Аграрная реформа Столыпина : [учебное пособие]. М. : МГУ, $1973.335 \mathrm{c}$. 
redistribution since they were allotted, and had not been subdivided for 24 years, the latter were removed from the final text of the Law. For homeowners of such properties the procedure was greatly facilitated. They were allowed to apply to relevant authorities with a request not to fix the fact of acquisition of the plot, but to prepare documents for ownership of it;

2. If in the first Decree the transfer of communities and villages with hereditary (yard or parcel) land ownership to the ownership in household cut areas was carried out by the decision of $2 / 3$ votes of homeowners with the voting right in the east, then according to the Law of June 14, 1910 it was envisaged to make a decision by a simple of majority votes;

3. In the absence of an ancestor in a family who was separated from the community, the responsibility for identifying the homeowner's personality rested with the village council. If, within a month, the community did not make the appropriate decision, the final version of the law enabled the Zemstvo chief to resolve the dispute by interviewing earlier the voting members of the rural assembly;

4. Introduced Art. 10 is missing in the first nominal Decree. It contained a rule under which owners of land plots and unallocated members of their families were deprived of a portion of publicly owned land, which until recently was distributed on a common ground;

5. To the decree of June 14, 1910 was introduced a rule on the right to dispose of subsoil land on allotment plots allocated to personal property. Article 20 entrusted the development of subsoil in these lands, except for the extraction of clay, sand, peat and rubble stones, with the community. It was the community that continued to be the owner of the subsoil of the lands transferred into the personal property from public lands;

6. The provisions of the two decrees obliged the community to satisfy the homeowner's request for getting allotment plots. However, in case it was impossible or inconvenient for the community to implement it, the latter could satisfy the peasant's interests with money, the amount of which was determined by the assessment of the land management commission. Article 34 of the Decree of June 14, 1910 established an exceptional list of cases in which the separation from the community could not be satisfied with the amount of money. The norm on the requirement of $1 / 5$ of a part of households as an unconditional basis for the community's decision to allocate land from its composition was missing in the Decree of November 9, 1906;

7. Unlike the Decree of November 9, 1906 in the case of intentions to purchase surplus land, a simplified procedure for the land evaluation was established. The Second Decree of June 14, 1910, fixed the rate of the land price. It was now to be determined at the initial average price for one-tenth of the land given to the community, which was subject to redemption payments (Article 12). 
8. According to the first Decree lands in so-called non-communal communities, were to be acquired only into personal property while according to the Law of June 14, 1910, they were to be both acquired and certified. Part of the land acts were issued on the demand of communities or villages, and the other part - on the demand of individual yards.

9. The Decree of June 14, 1910 has no norm of the yard as a legal entity.

Of course, there were other differences between the two imperial decrees, but there were no deep discrepancies and polar differences between them. Some asynchrony can be seen in stylistic references, editorial corrections, terminological clarifications and other non-basic details.

Finally, the Land Management Act and the appendix to Art. 64, entitled "On Land Management Commissions and their Land Measurement Part", dated 29 May 1911, crowned the legislative reform package and was to accelerate land management works in villages both with public and yard use of $^{34}$. Article 3 was the first to recognize the allotment plots of peasants and other rural inhabitants as privately owned lands. The concept of farmstead in this law was completely absent. According to the contents of the law, it was included only for household cut plots.

Article 28 fixed normatively the land use forms that had formed during the development of land relations after the liquidation of serfdom. In addition to public, community, worldly land use, there was also mixed one. The latter included such a kind according to which some members of the community with public land use owned their plots as their personal ownership.

The regulation gave land management commissions broad powers for making the final decision on the withdrawal of peasants from the community. It was they who were allowed to authorize the allotment of land into household cut plots. The allocation of arable land took place on the demand of even one homeowner, if a separate land management commission considered such an action expedient and not harmful to the individual community. Otherwise an identical separation mechanism was applied by the decision of the village assembly if it was desired by the fifth of persons who had the right to vote provided the community did not exceed 250 homeowners. In communities with a greater number of homeowners, 50 votes were sufficient (Article 36).

All types of land tenure, including the parcel of land of private or individual backyard owners, purchased from the Peasant Bank or with its assistance by rural communities and peasant societies with public ownership, came under the validity of this legal act. The Allotment of land was held by

34 Закон о землеустройстве. Полн. собр. законов. Собр. 3. СПб. : Гос. типогр., 1914. T. XXX1. 1914. № 35370 . 
the voluntary agreement of the parties with the compulsory liquidation of (Art. 27). In the absence of the agreement it was done in the compulsory order. The latter case did not exempt the land management commission from the need to "strive for the amicable agreement of the parties" (Article 6).

The law greatly simplified the possibility of withdrawing to household cuts. The documents obtained as a result of this procedure were now considered sufficient to certify land ownership. Writing applications for leaving the community, the appropriate design of their portion of the allotment remained in the past. The peasants of communities in which the land was not divided were considered to be private owners. "The ultimate goal of land management, as defined in the Circular of the Yuzich of July 12, 1907, was to maximize the host approachment to his arable land by agricultural lands as close to the homestead as possible: commissions are to divide land plots offered for sale into separate ones for each yard so that each such area is one solid household cut and that its borders are convenient for farming" 35 .

\section{CONCLUSIONS}

So, realizing the complexity of approving legal norms through the legislative procedure born by the revolutionary events, P. Stolypin passed a number of laws regulating land legal relations by manifest order, by means of a mechanism of emergency legislation. The decree of November 9, 1906, was legitimized only after the dissolution of the State Duma of the first convocation the majority of which consisted of representatives of right-wing political forces. The proposed variant of continuation of the land reform did not suit the left wing of the State Duma either. Only four years later, when the results of the reform became obvious and public opinion was well-prepared, the State Duma of the third convocation, after lengthy discussions, adopted the "Regulation on the Amendment and Supplement of Some Resolutions on Peasant Land Ownership", approved by the Imperial Decree of June 14, 1910.

The ideas of both Decrees (of November 9, 1906 and June 14, 1910) were absolutely identical and were intended to promote the peasant masses' withdrawal from public custody and the securing of allotment of land for the homeowner, not for the family. The laws did not envisage any grounds other than the will of the very subjects of relations, for prohibiting the "privatization" of allotment plots. The procedure for the allocation and acquisition of public land into personal property was prescribed in such a way that those wishing to become owners got the maximum assistance in leaving the community.

35 Державний архів Житомирської області. Ф. 226. Оп. 1. Спр. 3. Арк. 120-128. Циркуляр ГУЗ и 3 от 12 июля 1907 г. 
In the fall of 1906, changes to the land legislation, the government pursued a policy of Bonapartism, waving between the two lights. Calming down the broad circles nobility with allegations about the creative development of the Regulations of February 19, 1861 and the absence of intentions to liquidate public land tenure by force the Stolypin paradigm of the land reform had this very purpose. This is evidenced by our analysis of the contents of the Decrees of November 9, 1906 and July 14, 1910, which confirms the innovative nature of these legislative acts.

\section{SUMMARY}

These are the main stages of Stolypin's agrarian reform, initiated by the Decree of November 9, 1906. This revolutionary provision finally destroyed public land ownership and opened the possibility for members of the community to move out of it and acquire land for private ownership. The very fact of the emergence of an alternative between public and personal land tenure testified that, in the sphere of land relations, the Russian Empire had firmly defined its vector - the orientation towards integrated European values. The validity of the imperial act extended to the territories of those provinces in which the public nature of land ownership prevailed. The western provinces of Russia, including Podil and Volyn with a court-hereditary system of land tenure, were not covered by the Decree of November 6, 1906.

A comparative legal analysis of the Decree of November 9, 1906 and its comparison with the Regulations of February 19, 1861.

\section{REFERENCES}

1. Аврех А. Я. П. А. Столыпин и судьбы реформы в России. М. : Политиздат, $1991.286 \mathrm{c}$.

2. Антошкин С. Н. Столыпинская аграрная реформа : [лекция]. М. : МЮИ, 1999. $21 \mathrm{c.}$

3. Бородин А. П. Реформы во имя России. М. : Вече, 2002. 380 с.

4. Боханов А. Н. Последний царь. М. : Вече, 2006. 512 с.

5. Герье В. Второе раскрепощение: общие прения по Указу 9 ноября 1906 года в Государственной Думе и Государственном Совете. М. : Печатня С. П. Яковлева, 1911. 232 с.

6. Дроздов В. П. Крестьянские законы. Права крестьян на землю. М. : Тип. П. П. Рябушинского, 1910. 39 с.

7. Дякин В. С. Черезвычайное указное законодательство в России (1906-1914). Был ли шанс у Столыпина? : сборник статей. СПб. : ЛИСС, 2002. C. $120-148$.

8. Закон 9 ноября 1906 года о выходе из общины, с разъяснениями. М. : Юристъ, 1908. 85 с. 
9. Законодательные акты переходного времени, 1904-1908 гг. СПб. : Тов-тво по изданию новых законов, 1909. 982 с.

10. Зырянов П. Н. Крестьянская община Европейской России: 19071914. М. : МГУ, 1992. 286 с.

11. Климин И. И. Столыпинская аграрная реформа и становление крестьян-собственников в России. СПб. : Клио, 2002. 348 с.

12. Кузьмин-Караваев В. Д. "Революционные выступления" Думы и земельный вопрос. СПб. : Б. в., 1906. 42 с.

13. Ламздорф П. К. Высочайший Указ 9 ноября 1906 года и семейная собственность у крестьян. СПб. : Сенатская типография, 1909. 27 с.

14. Обзор деятельности Главного управления Землеустройства и Земледелия за 1910 г.г. СПб. : Тип. В. Ф. Киршбаума, 1911. 380 с.

15. Самарин Федор. Указ 9-го ноября 1906 года и Положение 19-го февраля 1861 года. М. : Печатня А. И. Снегиревой, 1908. 16 с.

16. Семенов Е. В. Краткие сведения по русскому земельному праву : пособие [для учеников землемерных училищ]. Псков : Тип. губернского земства. $35 \mathrm{c.}$

17. Сидельников С. М. Аграрная реформа Столыпина : [учебное пособие]. М. : МГУ, 1973. 335 с.

18. Столыпин П. А. Думские речи. М : Знание, 1990. 64 с. (Новое в жизни, науке, технике. Серия “Лекторское мастерство”. № 10).

19. Тютюрмов И. М. Закон 14 июня 1910 года об изменениях и дополнениях некоторых постановлений о крестьянском землевладении с законодательными мотивами и разъяснениями Правительствующего Сената (по 1 сентября 1910 года). - [изд. неоф.] СПб. : Издание юридического книжного магазина И. И. Зубкова под фирмою “Законоведение”, 1911. 181 с.

20. Хауке О. Русское землеустроительное законодательство. М. : Типолитография, 1910. 157 с. (Выпуск 1).

\section{Information about the author:} Zakharchenko P. P.,

Doctor of Laws, Professor at the Department of History of Law and State Law Faculty, Taras Shevchenko National University of Kyiv 60, Volodymyrska str., Kyiv, 01033, Ukraine 